\author{
${ }^{\odot}$ O. M. Krupnyk \\ Odesa National Medical University
}

\title{
OBSTETRICIANS' TACTICS IN THE DELIVERY BY PATIENTS WITH BREECH POSITION OF THE FOETUS AFFECTED BY THE UTERINE MYOMA
}

The aim of the study - improvement of pregnancy outcomes in women with pelvic presentation on the background of uterine myoma by developing optimal obstetric delivery tactics.

Materials and Methods. In order to achieve the stated goal, a prospective analysis of cases of first- and second-time delivering patients with full-term one fetus pregnancy in pelvic presentation (incomplete and complete) amid the uterine myoma - the main group $(M G)-(n=30)$ was conducted. Into the control group $(C G)-(n=30)$ were included the first- and second-time bearing women without fetal myoma with full-time pregnancy and the pelvic presentation. Statistical processing of the results was performed using the Microsoft Office Excel 2017 software.

Results and Discussion. The analysis of the presented data shows that among pregnant women with pelvic prevalence of fetuses on the background of uterine fibroids, more frequent cases are registered: clinical manifestations of the threat of interruption of pregnancy MG - $26(86.7 \%), C G-9(30 \%)$ and pre-eclampsia MG $-8(26.7 \%), C G-3(10 \%)(p<0.05)$. Raising the risk of complications of pregnancy and the expected birth of the uterine myoma requires pre-planning for the most part the operational method of delivery of MG $-19(63.3 \%)$. Exception, in the absence of other contraindications, there may be women with single myomatous nodes in sizes up to $5 \mathrm{~cm}-11(36.7 \%)$. Only the extension of the cesarean section requires only pregnant women with uterine myoma 7 (36.8\%), and most of these interventions occur during precarious surgical delivery 4 (20 \%).

Conclusion. Consequently, the presented data indicate the expediency and validity of taking into account the presence of uterine myoma at BP in order to develop an optimal obstetric tactic for the delivery of such patients in order to improve their pregnancy outcomes.

Key words: pelvic fetal pregnancy; uterine myoma; cesarean section; conservative childbirth.

АКУШЕРСЬКА ТАКТИКА ПРИ РОЗРОДЖЕННІ ПАЦІЄНТОК ІЗ ТАЗОВИМ ПЕРЕДЛЕЖАННЯМ ПЛОДА НА ТЛІ МІОМИ МАТКИ

Мета дослідження - покращити наслідки вагітності в жінок із тазовим передлежанням плода на тлі міоми матки шляхом розробки оптимальної акушерської тактики розродження.

Матеріали та методи. Проведено проспективний аналіз випадків розродження першо- та повторнороділей із доношеною вагітністю одним плодом у тазовому передлежанні на тлі міоми матки - основна група (OГ) (n=30). Контрольна група (КГ) ( $\mathrm{n=30)}$ - першо- та повторнороділлі без міоми матки із доношеною вагітністю у тазовому передлежанні плода. Статистичну обробку отриманих результатів проводили за допомогою програмного забезпечення Microsoft Office Excel 2017.

Результати дослідження та їх обговорення. Встановлено, що серед жінок ОГ частіше реєструються випадки клінічних проявів загрози переривання вагітності: ОГ - 26 (86,7 \%), КГ - 9 (30 \%), та прееклампсії: ОГ - 8 (26,7 \%), КГ - 3 (10 \%) (р<0,05). Пацієнтки ОГ потребують попереднього планування здебільшого оперативного способу розродження - 19 (63,3 \%). Кандидатами для планування консервативних пологів, за відсутності інших протипоказань, можуть бути жінки із поодинокими міоматозними вузлами розмірами до 5 см - 11 (36,7 \%). Розширення операції кесаревого розтину потребують виключно вагітні ОГ - 7 (36,8 \%), більшість зазначених втручань відбувається саме під час ургентного оперативного розродження - 4 (20 \%).

Висновки. Вагітні жінки із тазовим передлежанням плода на тлі міоми матки потребують попереднього покрокового консультування щодо обрання індивідуального способу розродження. Доцільність такого підходу полягає у сприятливому його впливі на наслідки вагітності як для дитини, так і для жінки.

Ключові слова: тазове передлежання плода; міома матки; кесарів розтин; консервативні пологи.

АКУШЕРСКАЯ ТАКТИКА ПРИ РОДОРАЗРЕШЕНИИ ПАЦИЕНТОК С ТАЗОВЫМ ПРЕДЛЕЖАНИЕМ ПЛОДА НА ФОНЕ МИОМЫ МАТКИ

Цель исследования - улучшить исходы беременности у женщин с тазовым предлежанием плода на фроне миомы матки путем выработки оптимальной акушерской тактики родоразрешения.

Материалы и методы. Проведен проспективний анализ родов перво- и повторнородящих пациенток с доношенной беременностью одним плодом в тазовом предлежании на фоне миомы матки - основная группа (ОГ) ( $\mathrm{n}=30)$. Контрольная группа (КГ) $(\mathrm{n}=30)$ - перво- и повторнородящие женщины без миомы матки с доношенной беременностью в тазовом предлежании плода. Статистическую обработку полученных результатов проводили с помощью программного обеспечения Microsoft Office Excel 2017.

Результаты исследования и их обсуждение. Установлено, что среди женщин ОГ чаще регистрируются случаи угрозы прерывания беременности: ОГ - 26 (86,7 \%), КГ - 9 (30 \%), и преэклампсии: ОГ - 8 (26,7 \%), КГ - $3(10$ \%) $($ р<0,05). Пациентки ОГ требуют предварительного планирования в основном оперативного родоразрешения - 19 (63,3 \%). Кандидатами для планирования консервативных родов, при отсутствии других противопоказаний, могут быть женщины с единичными миоматозними узлами размерами до 5 см - 11 (36,7\%). В расширении объема кесарева сечения нуждаются исключительно беременные ОГ - 7 (36,8 \%), большинство указанных вмешательств происходит именно во время ургентного оперативного родоразрешения-4 (20\%).

Выводы. Беременные женщины с тазовым предлежанием плода на фроне миомы матки требуют предварительного пошагового консультирования относительно выбора индивидуального способа родоразрешения. Целесообразность такого подхода заключается в благоприятном его влиянии на исходы беременности как для ребенка, так и для женщины.

Ключевые слова: тазовое предлежание плода; миома матки; кесарево сечение; консервативные роды. 
INTRODUCTION. Uterine myoma and pregnancy comprise a problem with the urgency, caused, first of all, by the increase in the age of child-bearing women in the XXI century. So, accordingly to many researchers in the world, 0.4 to $6 \%$ of pregnancies now progress and end right on the background of uterine myoma. And among the numerous complications caused by fibrous tumors of the uterus should be counted the pelvic presentation or breech position of the fetus (BP) $[1,4]$. Accordingly to the literature, the pregnancy with the BP, which was the result of an uterine myoma, is characterized by a range of inevitable gestational complications (35-80 \%) and always ending with a caesarean section $[3,5,8]$. However, special attention of scientists is drawn to the cesarean section in women with uterine myoma that mostly accompanied by growth of surgery scope (myomectomy, hysterectomy), as well as the increase in intraoperative blood loss [2, 6]. In turn, numerous scientific data on the lack of unambiguous dependence of BP on the uterine fibroids and the possibility of completing most of the myopic pregnancies in the physiologically normal way dictate the need for further research in the chosen direction in order to develop an individual differentiated approach to patients with BP with the uterine myoma, especially in the process of delivery the fetus $[7,9]$.

THE AIM OF THE STUDY - improvement of pregnancy outcomes in women with BP on the background of uterine myoma by developing optimal obstetric delivery tactics.

MATERIALS AND METHODS. In order to achieve the stated goal, a prospective analysis of cases of first- and second-time delivering patients with full-term one fetus pregnancy in pelvic presentation (incomplete and complete) amid the uterine myoma - the main group $(M G)-(n=30)$ was conducted. The "duration time" of the uterine fibroids in MG was (3.14 \pm 2.18$)$ years. Prior to the onset of the present pregnancy, no conservative or operative treatment was carried out in any case. Patients with congenital malformation abnormalities, preterm labor ( $<37$ weeks), multiple congenital malformations of birth canals, pregnancy and fetus were excluded from the study. All deliveries took place at the third level of obstetrical care in the Odesa Regional Perinatal Center in 2016-2018. Into the control group $(C G)-(n=30)$ were included the first- and second-time bearing women without fetal myoma with full-time pregnancy and the BP.

Statistical processing of the results was performed using the Microsoft Office Excel 2017 software. Statistically significant values were considered as $p<0.05$.

RESULTS AND DISCUSSION. Clinical and statistical analysis of the data shows that the age of the patients in the study groups did not differ significantly and was in the MG - (33.2 \pm 0.18$)$ years, in CG - (32.7 \pm 1.39$)$ years $(p>0.05)$.

Study of the somatic status of the pregnant women found the evidence of the presence of such extragenital pathology as: diseases of the thyroid gland within MG $-4(13.3 \%)$, CG - 4 (13.3\%); cardiovascular disease in MG - 9 (30\%), CG $-7(23.3 \%)$ and urinary system MG - 5 (16.7\%), CG $-7(23.3 \%)(p>0.05)$.

The assessment of the character of the menstrual function drew attention to: late, at the age of 15-16 years, menarche 10 (33.3\%) - MG, 8 (26.7\%) - CG and dysmenorrhea $13(43.3 \%)$ - MG, $11(36.7 \%)$ - CG in the patients of both groups $(p>0.05)$.

Concerning the adverse consequences of previous pregnancies in the study groups, they differed significantly in number and structure. Thus, in MG cases (one and more) the termination of pregnancy up to 12 weeks of gestation at their own will was registered among 21 (70 \%) patients. While women within the CG indicated only natural loss of pregnancy 10 (33.3\%): spontaneous miscarriage - 6 (20\%) and missed miscarriage $-4(13.3 \%)(p<0.05)$.

It was found within the obstetric history: primipregnancy in $M G-9(30 \%)$ in CG - $19(63.3 \%)$ women $(p<0.05)$. The complications of previous childbirth and postpartum period were not found in both groups.

All the patients in the study groups were registered during the first trimester of gestation and attended the women's consultation on a regular basis.

The pregnancy follow-up in women from MG and CG has shown almost always the same early toxicosis 6 (20\%) - MG, $8(26.7 \%)-C G$ and light stage anemia of pregnant women $7(23.3 \%)$ - MG, $5(16.7 \%)$ - CG ( $p>0.05)$. Cases of complication of gestation such as preeclampsia with a moderate and severe course was more commonly recorded among MG patients $-8(26.7 \%)$. In CG, this pathology was shown to be of only moderate severity in 3 pregnant women $(10 \%)(p<$ 0.05). Symptoms of the threat of abortion were significantly more likely to disturb patients with uterine myoma: MG - 26 $(86.7 \%), C G-9(30 \%)(p<0.05)$. It is also worth attention that their clinical manifestations in MG occurred quite early and had a lasting and sustained character.

It should be emphasized that the presence of uterine myoma in MG patients in no way interfered with the need to prolong pregnancy and did not require premature delivery.

Thus, natural, through birth canals, ending of the pregnancy was seen in 11 (36.7\%) MG patients and 24 (80\%) of the CG patients $(p<0.05)$. Women in MG with BP with spontaneous vaginal delivery have revealed some subserous or intramuscular myoma nodes in sizes not more than $5 \mathrm{~cm}$ with localization in the body and lower segment of the uterus. All conservative births of MG patients have been planned in advance. It has been established that the presence of myomatous nodes of the above character does not negatively affect the length of labor and the course of the postpartum period. Thus, the average duration of labor in MG with primipregnancy was $(664.31 \pm 47.12) \mathrm{min}$, with second birth - (558.83 \pm 18.33$) \mathrm{min}$; in CG $(634.16 \pm 25.66)$ $\min$ and $(501.52 \pm 39.29) \mathrm{min}$, respectively $(p>0.05)$. The average duration of the anhydrous period in the study groups also did not differ significantly: MG - (346.12 \pm 24.02$) \mathrm{min}$, CG - (313.54 \pm 34.31$)$ min ( $p>0.05)$. Regarding the complications of the sequential period, they have not occurred in any case, and the length of this period reached in the MG $(19.27 \pm 1.14) \mathrm{min}$, in CG $-(22.09 \pm 0.36) \mathrm{min}(p>0.05)$. Blood loss within these childbirths was exclusively physiological, but somewhat higher among MG patients $(344 \pm 27.38 \mathrm{ml})$, than within CG $(226 \pm 18.72 \mathrm{ml})(\mathrm{p}<0.05)$.

Accordingly to our studies, operational delivering in BP was significantly more frequent in MG - 19 (63.3\%), whereas the amount of such cases in CG patients was registered three times less $-6(20 \%)$ cases $(p<0.05)$. It should be stated that in the MG the indicated method of delivery was planned for 38.5 week of gestation in all $19(63.3 \%)$ women. This approach was especially due to the fibrous uterus tumor: it had multiple nodes, some nodes with centripetal growth, their localization in the lower segment of the uterus or large sizes - from 5 to $16 \mathrm{~cm}$. However, the studied CG where 
pregnancy ended with a Caesarean section were in no case previously planned for it.

It was seen that the pre-selected mode of operational delivery in the MG was not always performed at the scheduled time. Thus, within the cesarean in the MG were recorded 5 $(26.3 \%)$ cases of urgent delivery with: placental abruption 2 (10.5\%), amniotic fluid leak $1(5.3 \%)$ and severe preeclampsia 2 (10.5\%).

It was needed to expand the scope of the operation in 4 (20\%) cases in the MG: hysterectomy $2(10.5 \%)$ cases and stage-by-stage uterine devascularization $2(10.5 \%)$ cases. At the same time, the need of surgical procedure to complete the pregnancy for MG patients urgently looked slightly different way: the weakness of delivery labor $3(20 \%)$, intra-natal distress of the fetus $1(16.7 \%)$ and the immaturity of the birth canals while loss of amniotic fluid 2 (33.3\%). There were no cases of extension of cesarean section OP in CG.

In the analysis of cases of planned caesarean section 14 (73.7) in MG patients, it was seen that most of the operations ended without the need for extension - 11 (57.9\%). However, the extension, which was needed at planned operational delivery, was limited to: myomectomy $2(10.5 \%)$ cases and the phase of devascularization of uterus $1(5.3 \%)$ case.

In both groups were 30 newborns. The average weight of newborns in MG was $(3015 \pm 124) \mathrm{g}$, in CG - $(3560 \pm 275) \mathrm{g}$ ( $\mathrm{p}$ $<0.05)$. The average clinical assessment of the newborns on the Apgar scale on the first (MG - $(7.4 \pm 0.3)$; CG - (7.7 \pm 0.6$)$ points) and the fifth (MG - (8.7 \pm 1.7$), C G-(8.5 \pm 1.4)$ points) minutes of life testified to the absence of significant differences among the observed groups $(p>0.05)$.

Consequently, the presented data indicate the expediency and validity of taking into account the presence of uterine myoma at BP in order to develop an optimal obstetric tactic for the delivery of such patients in order to improve their pregnancy outcomes.

CONCLUSIONS. 1. Study of the structure of gestational complications in patients of the presented groups indicates that their occurrence is significantly more common in patients with uterine myoma. Among pregnant women with this pathology, significantly more frequent are registered cases of: clinical manifestations of the threat of pregnancy termination
- in the MG - $26(86.7 \%)$, CG - $9(30 \%)$ and preeclampsia - MG - $8(26.7 \%), C G-3(10 \%)(p<0.05)$. The mentioned complications in the MG are mostly characterized by an early occurrence and steady course.

2. The influence of uterine myoma on the determination of the mode of delivery in the cases of fetal pelvic position is proved. Raising the risk of complications of pregnancy and childbirth, this pathology of the uterus requires preliminary planning of the mostly operative delivery method -19 cases in the MG (63.3\%). In the absence of other contraindications, women with single myomatous nodes up to $5 \mathrm{~cm}$ can be considered excluded, when the step-by-step approach in choosing the conservative method of delivery with pelvic preposition on the background of uterine myoma is expected to give favorable outcome - $11(36.7 \%)$.

3. Analysis of indications for urgent operational delivery of the MG patients indicates the probability of existing in them first-time disorders of the utero-placental vessels that may occur with such decompensation on the eve of delivery as: premature detachment of normally located placenta -2 cases $(10.5 \%)$ and pre-eclampsia of severe degree -2 cases (10.5\%).

4. Expansion of the operation of cesarean section was used exclusively in patients with uterine myoma -7 cases $(36.8 \%)$. The most cases of this intervention were carried out precisely during the urgent operative delivery 4 (20\%). Whereas, elective caesarean section needed in lower number of cases $-3(15.8 \%)$, and with less expansion in operation scope $(p<0.05)$.

5. Clinical reflection of the primary vascular disorders and the negative influence of uterine myoma on the formation and tense functioning of the fetoplacental complex throughout the pregnancy were significantly lower anthropometric indices (weight) of newborns in MG - $(3015 \pm 124) \mathrm{g}$, in CG $-(3640 \pm 275) \mathrm{g}(\mathrm{p}<0.05)$.

PERSPECTIVES OF FURTHER RESEARCH. The research perspective in the chosen area will be an opportunity of considering the type of uterine myoma while determining the best way of delivery for patients with uterine fibroids and breach presentation. Such a balanced approach should have a beneficial effect on maternity and perinatal indexes for women with the indicated problem.
LIST OF LITERATURE

1. Alekhin M. N. Pregnancy and childbirth of high risk / M. N. Alekhin, O. Yu. Caleva, B. A. Sidorenko // Obstetrics. 2012. - No. 11. - P. 9-13.

2. Fominova G. V. The course of the gestation process and the delivery of patients with the myoma of the uterus / G. V. Fominova, N. A. Lyalichkina, Yu. Kosenko // Modern Problems of Science and Education. - 2018. - No. 4.

3. Cochrane Effective Practice and Organization of Care (EPOC). The proposed risk of bias criteria for EPOC reviews. EPOC Resources for review authors, 2017. London : Cochrane; 2017 [Electronic resource]. - Mode access : http://epoc.cochrane. org/epoc-specificresources-review-authors. Accessed 8 May 2017.

4. Ouyang D. W. Pregnancy in women with uterine leiomyomas (fibroids): Literature review [Electronic resource] / D. W. Ouyang, E. R. Norwitz // UpToDate, Inc. - 2014. - Mode access : http:// www.uptodate.com/content/pregnancy-in-women-with-uterineleiomyomasfibroids (date of reference March 18, 2014).
5. Stewart E. A. Clinical practice. Uterine fibroids / E. A. Stewart// N. Engl. J. Med. -2015. - Vol. 372. -P. 1646-1655.

6. Outcomes after Caesarean myomectomy versus cesarean alone among pregnant women with uterine leiomyomas I H. O. Topcu, C. T. Iskender, H. Timur [et al.] // International Journal of Gynecology and Obstetrics. - 2015. - Vol. 130. - P. 244-246.

7. WHO recommendations for antenatal care for a positive pregnancy experience. Geneva: World Health Organization; 2016 [Electronic resource]. - Mode access : http://www.who. int/nutrition/publications/guidelines/antenatalcare-pregnancypositive-experience. Accessed 1 June 2018

8. The WHO Working Group on Caesarean Section. WHO statement on caesarean section rates. BJOG. - 2016. - Vol. 123 (5). - P. 667-670. doi 10.1111 / 1471-0528.13526.

9. Caesarean section rates in subgroups of women and perinatal outcomes / J. Zhang, C. Geerts, C. Hukkelhoven [et al.] // BJOG. - 2016. - Vol. 123 (5). - P. 754-761. 
REFERENCES

1. Alekhin, M.N., Caleva, O.Yu., \& Sidorenko, B.A. (2012). Pregnancy and childbirth of high risk. Obstetrics, 11, 9-13.

2. Fominova, G.V., Lyalichkina, N.A., Kosenko, Yu.Yu., Fominova, I.S., \& Zakharov, A.A. (2018). The course of the gestation process and the delivery of patients with the myoma of the uterus. Modern Problems of Science and Education, 4.

3. EPOC: Resources for review authors (2017). Cochrane Effective Practice and Organization of Care (EPOC). The proposed risk of bias criteria for EPOC reviews. London: Cochrane. Retrieved from: http://epoc.cochrane.org/epocspecificresources-review-authors.

4. Ouyang, D.W., \& Norwitz, E.R. (2014). Pregnancy in women with uterine leiomyomas (fibroids): Literature review. UpToDate, Inc. Retrieved from: http://www.uptodate.com/ content/pregnancy-in-women-with-uterine-leiomyomasfibroids.

5. Stewart, E.A. (2015). Clinical practice. Uterine fibroids. N. Engl. J. Med., 372, 1646-1655.
6. Topcu, H.O., Iskender, C.T., Timur, H., Kaymak, O., Memur, T., \& Danışman, N. (2015). Outcomes after Caesarean myomectomy versus cesarean alone among pregnant women with uterine leiomyomas. International Journal of Gynecology and Obstetrics, 130, 244-246.

7. (2016). WHO recommendations for antenatal care for a positive pregnancy experience. Geneva: World Health Organization. Retrieved from: http://www.who.int/nutrition/ publications/guidelines/antenatalcare-pregnancy-positiveexperience.

8. (2016). The WHO Working Group on Caesarean Section. WHO statement on caesarean section rates. BJOG, 123 (5), 667-670. doi 10.1111 / 1471-0528.13526.

9. Zhang, J., Geerts, C., Hukkelhoven, C., Offerhaus, P., Zwart, J., \& de Jonge, A. (2016). Caesarean section rates in subgroups of women and perinatal outcomes. BJOG, 123 (5), 754-761. 